\title{
Crown morphometry for two valuable timber species from Miombo woodland in Mozambique
}

\author{
Noé dos Santos Ananias HOFIÇO1*, Emanuel Arnoni COSTA², Frederico Dimas FLEIG ${ }^{3}$, \\ César Augusto Guimarães FINGER ${ }^{3}$
1Department of Forest Engineering, Zambeze University - UniZambeze, Mocuba, Zambézia, Mozambique. ${ }^{2}$ Department of Forest Engineering, Federal University of Uberlândia, Monte Carmelo, MG, Brazil. ${ }^{3}$ Department of Forest Sciences, Federal University of Santa Maria, Santa Maria, RS, Brazil. *E-mail: noe.hofico@gmail.com \\ (Orcid: 0000-0003-2554-4576; 0000-0002-0644-2403; 0000-0003-1683-3157; 0000-0003-1622-2399)
}

\begin{abstract}
Recebido em 06/04/2021; Aceito em 12/07/2021; Publicado em 19/07/2021.
ABSTRACT: Pterocarpus angolensis DC and Bobgunnia madagascariensis (Desv.) J. H. Kirkbr. \& Wiersema are two hardwood species found in Miombo woodland. Crown size, being closely related to the photosynthetic capacity of a tree, is an important parameter in studies of the growth of individual trees. In this sense, the present study aimed to study the morphometric relationships of $P$. angolensis and B. madagascariensis as a resource to describe the morphometric features of these species. Data were sampled in 60 rectangular plots of $20 \times 50 \mathrm{~m}$, systematically distributed within the forest. In each plot, the diameter at breast height (DBH), height (h), crown insertion point (cih) and four crown radii of all trees with $\mathrm{DBH} \geq 10 \mathrm{~cm}$ were measured. Results indicated that crown diameter and crown length of $P$. angolensis grow as DBH and height increase, the larger the crown, the greater the trees dimensions; as for B. madagascariensis, crown features have shown low correlation when considering DBH. It was concluded that crown features influence on tree growth and are important measures of description and planning of silvicultural activities to be performed in natural forests. The results are of interest to forest managers since they make decisions about silvicultural operations.
\end{abstract}

Keywords: crown dimensions; prediction models; umbila; pau-ferro; forest management.

\section{Morfometria da copa para duas espécies madeireiras comerciais da floresta de Miombo em Moçambique}

\begin{abstract}
RESUMO: Pterocarpus angolensis DC e Bobgunnia madagascariensis (Desv.) J. H. Kirkbr. \& Wiersema são duas espécies de madeira de lei encontradas na floresta de Miombo. O tamanho da copa, está intimamente relacionado à capacidade fotossintética de uma árvore, e é um parâmetro importante nos estudos do crescimento de árvores individuais. Nesse sentido, o presente estudo teve como objetivo estudar as relações morfométricas de P. angolensis e B. madagascariensis como recurso para descrever as características morfométricas dessas espécies. Os dados foram obtidos em 60 parcelas retangulares de 20 x $50 \mathrm{~m}$, distribuídas sistematicamente na floresta. Em cada parcela, foram medidos o diâmetro à altura do peito (DAP), altura (h), altura de inserção da copa (hic) e quatro raios da copa de todas as árvores com DAP $\geq 10 \mathrm{~cm}$. Os resultados indicaram que o diâmetro e o comprimento da copa de $P$. angolensis crescem com o aumento do DAP e da altura; quanto maior a copa, maior dimensão das árvores, enquanto que para B. madagascariensis, as características da copa mostraram baixa correlação ao considerar o DAP. Concluiu-se que as características da copa influenciaram no crescimento das árvores e são importantes medidas de descrição e planejamento das atividades silviculturais a serem realizadas na floresta. Estes resultados são de interesse dos manejadores florestais, pois são eles que tomam decisões sobre as operações silviculturais.

Palavras-chave: dimensões da copa; modelos preditivos; umbila; pau-ferro; manejo florestal.
\end{abstract}

\section{INTRODUCTION}

Pterocarpus angolensis DC (known as Umbila) and Bobgunnia madagascariensis (Desv.) J. H. Kirkbr. \& Wiersema (known as Pau-ferro) are deciduous trees species of the Fabaceae family found in Dry tropical forests in Southern and Eastern Africa, including Miombo woodland (VAN WIK; VAN WIK, 2011). Miombo woodland is a vast African Dryland Forest ecosystem covering close to 2.7 million $\mathrm{km}^{2}$ across Angola, Democratic Republic of the Congo, Malawi, Mozambique, Tanzania, Zambia and Zimbabwe. The Miombo woodland is dominated by trees of the genera Brachystegia, Julbernardia and
Isoberlinia, in association with others species (CAMPBELL et al., 2008). The woodland plays a crucial role in formal and informal economies, supporting the livelihoods of millions of rural and urban people, by providing important resources such as timber, food, medicines, also play an important role in the ecosystem dynamics, particularly with respect to biodiversity, water, carbon and energy balance (KALABA et al., 2014; RYAN et al., 2016).

In Mozambique, forestry is one of the 10 largest industries in the country and accounted for a significants 
share of annual exports. For example, in 2019 the overall forest sector accounted for approximately $\$ 570$ million to the gross domestic product (WORLD BANK, 2020). Despite the large number of valuable tree species in Mozambique, two species $-P$. angolensis and B. madagascariensis, represented the bulk (44\%) of timber harvest between 1999 and 2014, and despite strict national-level Regulation of harvest, many are concerned that harvest may be occurring in an unsustainable manner (EGAS et al., 2013; MITADER, 2018).

Recently (March 2018), as a result of massive illegal logging and exports the Government of Mozambique has banned the harvest of two out of the six most exploited timber species (e.g., Combretum imberbe and Bobgunnia madagascariensis) and the export of Afzelia quanzensis, Millettia stublmannii and Pterocarpus angolensis and has suspended the development of new timber concession areas (REMANE; THERRELL, 2019). Even with reforms in the forestry sector, there remains doubt regarding strategies that could allow interventions of sustainable management and ways to optimize timber production in forests and raised the need for their conservation.

Despite the economic value of these species, relatively little research has focused on determining appropriate, biological-based crown variables and morphometric features schemes to help ensure that it is growth (including biomass), productive potential of several native species in Mozambique and make decisions about silvicultural operations (GELDENHYUS, 2005; HOFIÇO et al., 2018; MITADER, 2018). The current demand for timber from these species in the country, creates a need for tools for specific measurements that support the management and use of the existing stock.

A detailed investigation about crown features can contribute to understanding the management of ecosystem features such as forest productivity, biodiversity, and wildlife habitats (WEISKITTELL et al., 2011). Thus, in order to manage native forest species, it is necessary to know the characteristics of tree dynamics throughout time, what requires the description of morphometric relationships of species to optimize silvicultural techniques (SEIFERT et al., 2014; HESS et al., 2016).

Understanding morphometric relationships allows to provide information about features of the adjustment of crown morphology caused by competition for environmental resources in forest communities (SEIFERT et al., 2014; HESS et al., 2016), and studies about crown features (size and architecture) are fundamental to model tree growth (PRETZSCH, 2009). Modelling factors that influence on tree growth, reflected on the variation of size and shape, allow to establish strategies for the management of forest resources (WEISKITTELL et al., 2011).

Considering individual trees, it allows to infer about each one specifically by applying directly in forests and populations of different ages, in trees of distinct social positions because it mainly provides information about the suitable living space according to tree size (SEIFERT et al., 2014). Thus, size, structure, shape, and distribution of crowns are intimately related to tree growth, growth strength and productivity (GONZALEZ-BENECKE et al., 2014), volume and biomass (MATE et al., 2014; JUCKER et al., 2016), as well as wood quality, branch diameter, length of growth ring, trunk conicity, knot features, core and sapwood proportion (GONZALEZ-BENECKE et al., 2014; VON HOLSBEECK et al., 2016).
Moreover, crown dimensions reflect the competition the tree was subject to during its past growth (RUSSELL et al., 2014, FU et al., 2017), this being relevant information for the forester. Models that describe growth regarding individual trees are usually based on diameter at breast height, crown length and its interactions with dendrometric variables, with emphasis on the morphometric indexes such as h/DBH relationship, crown proportion, salience index, coverage index and formal of crown (COSTA et al., 2016; HESS et al., 2016).

In light of this, the present study aimed to investigate the dimensional relationships of $P$. angolensis and $B$. madagascariensis as a resource for the description of morphometric features of these species in a Miombo woodland in Mozambique. The proposed model can be used for predictions of crown morphometry involving these important species and provide resources for the country's management plans and make decisions about silvicultural operations.

\section{MATERIAL AND METHODS}

\subsection{Study area}

The study was performed in a forest concession that managed by Sotomane Construction and Industry Lda $\left(16^{\circ} 33^{\prime} \mathrm{S}\right.$ and $36^{\circ} 32^{\prime} \mathrm{E}, 16^{\circ} 49^{\prime} \mathrm{S}$ and $\left.36^{\circ} 47^{\prime} \mathrm{E}\right)$, located in Mocuba District, Zambézia Province, in central Mozambique (FIGURE 1). The main activity in the forest concession is the selective cut for wood-producing purposes. However, family subsistence agriculture is the predominant activity of local communities, characterized by slash and burn of the whole forest cover (clear cuts), resulting in annual fires and degradation of these areas (HOFIÇO; FLEIG, 2015).

The climate in the region is Aw (tropical savanna) according to the Köppen classification system, with welldefined seasons, dry winter from April to October, and wet season from November to March. The annual mean rainfall is $1200 \mathrm{~mm}$ and mean temperature is $24.3^{\circ} \mathrm{C}$. Soils are predominantly red argisoils in hydromorphic conditions (MAE, 2005). Topography is slightly undulated between 200 $\mathrm{m}$ and $400 \mathrm{~m}$ above sea level.
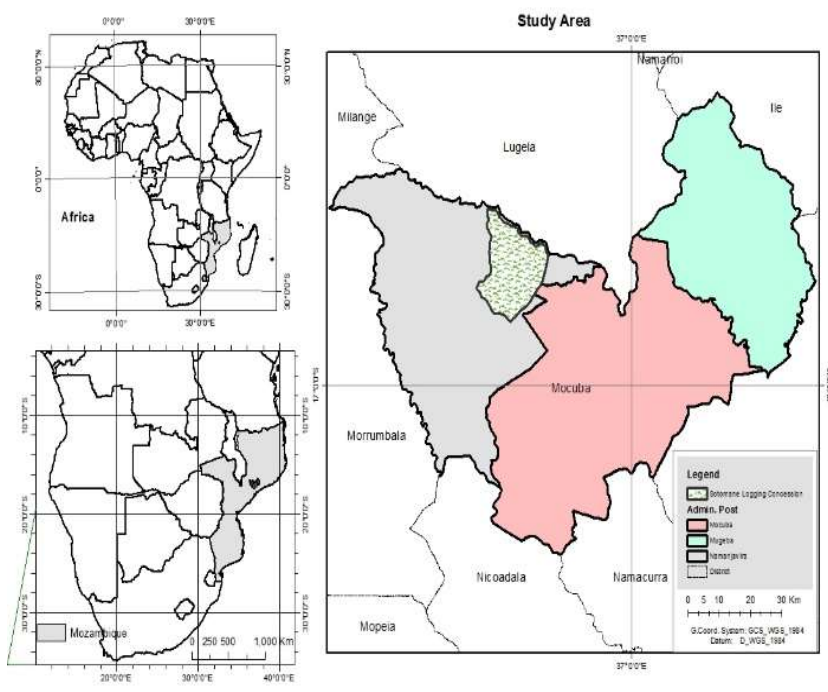

Figure 1. Study area in Mocuba District, Zambézia Province, Mozambique.

Figura 1. Área de estudo no Distrito de Mocuba, Província da Zambézia, Moçambique. 


\subsection{Description of studied species}

The Miombo woodland covers an area of 26.9 million ha in Mozambique and corresponds to $67 \%$ of its total forest area, being the main source of hardwood in the country (MITADER, 2018). P. angolensis is a medium to large-sized tree, up to $16 \mathrm{~m}$ tall that can reach $28 \mathrm{~m}$. It has a rectilinear and uniform trunk, a robust round-shaped crown, with a dark-brown core and yellow-greyish sapwood, wood is hard and moderately heavy, relatively easy to handle (Figure $2 \mathrm{a}$ ). As for B. madagascariensis, it is a small-sized tree varying between 4 and $16 \mathrm{~m}$ tall, with rectilinear uniform trunk and dense, robust and round-shaped crown (Figure 2b), its wood is hard and very heavy, hard to be handled, and it shows no significant difference in colour between core and sapwood (BUNSTER, 2006; MOJEREMANE; LUMBILE, 2016).
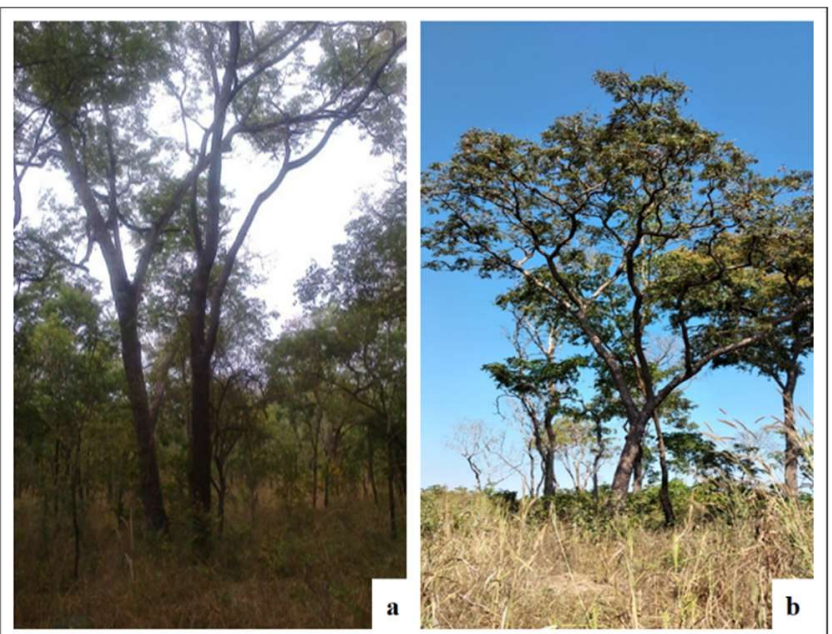

Figure 2. Typical growth forms of tree species in Miombo woodland, in Mocuba District, Mozambique, dry season 2020. (a) Pterocarpus angolensis; and (b) Bobgunnia madagascariensis.

Figura 2. Formas de crescimento típicas das duas espécies árboreas na floresta de Miombo, no Distrito de Mocuba, Moçambique, estação seca de 2020. (a) Pterocarpus angolensis; e (b) Bobgunnia madagascariensis.

Due to their physico-mechanical features such as durability, resistance, density and colour, B. madagascariensis and $P$. angolensis are species of high commercial value used in the construction, naval and furniture industry, as well as vehicle bodies, railroad ties, wood floor and decks, and beehives (BUNSTER, 2006; ALI et al., 2008). Additionally, parts of these species are widely used in traditional medicine to treat diseases such as malaria, cornea ulcer, mycosis, fever, and syphilis (STEVENSON et al., 2010; MOIEREMANE; LUMBILE, 2016).

\subsection{Data acquisition}

Data were obtained from 60 plots of $20 \times 50 \mathrm{~m}\left(1000 \mathrm{~m}^{2}\right)$ systematically distributed within a forest concession, with a distance of $50 \mathrm{~m}$ between plots, and $100 \mathrm{~m}$ between lines. For each objective tree, dendrometric and morphometric variables of all trees with $\mathrm{DBH} \geq 10 \mathrm{~cm}$ were measured, totaling 171 trees of $P$. angolensis and 115 trees of $B$. madagascariensis, covering the full range of diameters. The measured variables were diameter at breast height $(\mathrm{DBH})$ at $1.3 \mathrm{~m}$ above ground; height $(\mathrm{h})$, corresponding to the distance between ground level and crown top; commercial height (ch), corresponding to the trunk with commercial value; and height from the crown insertion point (cih) corresponding to the distance between ground level and the beginning of living crown. DBH was measured with a precision dendrometric caliper $(\mathrm{cm})$, height $(\mathrm{m})$ with the Blume-Leiss tool, and four crown radii in the cardinal points north, south, east, and west, with a measuring tape and compass. Crown length $(\mathrm{cl})$ was obtained with the difference between $\mathrm{h}$ and cih, in the expression [ $\mathrm{cl}=\mathrm{h}-\mathrm{cih}]$. Crown diameter (cd) was calculated in meters with the mean crown radium $(\mathrm{cr})$, in the expression $[\mathrm{cd}=\mathrm{cr} \times 2$ ] obtained from four radii.

\subsection{Data analysis}

Descriptive statistics characterized the measured variables. The diametric distribution was determined with the class range of $5 \mathrm{~cm}$, with the lower limit of the first class at $10.0 \mathrm{~cm}$, and $14.9 \mathrm{~cm}$ as upper limit. For the analysis of the morphometric relationships, the variables used were crown length $(\mathrm{cl})$, crown diameter $(\mathrm{cd})$, the $\mathrm{h} / \mathrm{DBH}$ relationship, or slenderness coefficient (SC), the $\mathrm{cd} / \mathrm{cl}$ relationship, known as formal of crown (FC), the $\mathrm{cd} / \mathrm{DBH}$ relationship, or salience index (SI), and the $\mathrm{cd} / \mathrm{h}$ relationship, or coverage index $(\mathrm{CI})$, according to the methodology described by Roman et al. (2009), Hess et al. (2016) and Costa et al. (2016). From the sampled data, the mean, minimal and maximum values of the morphometric variables and dimensional relationships of $P$. angolensis and B. madagascariensis were obtained, as shown in Table 1.

To describe the dimensional characteristics (h, cih, ch, cl, cd) according to $\mathrm{DBH}$, the biometric model 1 was adjusted in the non-linear model:

$$
y=\beta 0 \cdot \exp (\beta 1 / x)+\varepsilon i
$$

where: $\mathrm{y}$ - dimensional variable: $\mathrm{h}$; cih; ch; $\mathrm{cl}$; cd; $\mathrm{x}-\mathrm{DBH}$ (diameter at breast height, measured at $1.30 \mathrm{~m}$ above ground, in $\mathrm{cm}) ; \beta_{0}, \beta_{1}-$ estimated regression coefficient; $\varepsilon_{\mathrm{i}}-$ residual error.

And in order to describe the relationship of the morphometric variables (SC, FC, SI, CI), the biometric model was adjusted in the non-linear model:

$$
y=\beta_{0} \cdot X^{\beta 1}+\varepsilon_{i}
$$

where: y - dimensional variable: SC; FC; SI; CI; x - DBH (diameter at breast height, measured at $1.30 \mathrm{~m}$ above ground, in $\mathrm{cm}) ; \beta_{0}, \beta_{1}-$ estimated regression coefficient; $\varepsilon_{i}-$ residual error.

All statistics were processed with the SAS software version 9.1 (SAS Institute Inc. 2004). For the performance of the model, the coefficient of determination $\left(\mathrm{R}^{2}\right)$, root mean squared error (RMSE), and the graphic distribution of residues in percentage (Table 2). The dimensional variable by $\mathrm{DBH}$ and morphometric relationship of $P$. angolensis and $B$. madagascariensis was used to draw graphs in eight figures using the Microsoft Excel (2019). 
Table 1. Biometric characteristics of Pterocarpus angolensis and Bobgunnia madagascariensis in Miombo woodland in Mocuba District, Mozambique.

Tabela 1. Características biométricas de Pterocarpus angolensis e Bobgunnia madagascariensis na floresta de Miombo no Distrito de Mocuba, Moçambique.

\begin{tabular}{|c|c|c|c|c|c|}
\hline \multirow{2}{*}{ Variable } & \multirow{2}{*}{ Unit } & \multicolumn{2}{|c|}{ Pterocarpus angolensis } & \multicolumn{2}{|c|}{ Bobgunnia madagascariensis } \\
\hline & & Mean - SD & Range & Mean - SD & Range \\
\hline $\mathrm{DBH}$ & $\mathrm{cm}$ & $25.3 \pm 12.9$ & $10.0-66.7$ & $19.4 \pm 5.20$ & $10.0-38.6$ \\
\hline $\mathrm{h}$ & $\mathrm{m}$ & $11.1 \pm 3.10$ & $5.60-17.6$ & $11.0 \pm 2.10$ & $6.5-16.0$ \\
\hline cih & $\mathrm{m}$ & $5.70 \pm 1.60$ & $2.60-8.80$ & $4.10 \pm 1.00$ & $2.00-6.0$ \\
\hline $\mathrm{ch}$ & $\mathrm{m}$ & $4.50 \pm 0.90$ & $1.50-7.80$ & $4.50 \pm 1.20$ & $2.00-7.0$ \\
\hline $\mathrm{cl}$ & $\mathrm{m}$ & $5.40 \pm 1.70$ & $2.50-10.5$ & $6.90 \pm 2.00$ & $2.00-12.0$ \\
\hline $\mathrm{cd}$ & $\mathrm{m}$ & $6.70 \pm 1.30$ & $3.80-9.30$ & $2.00 \pm 0.50$ & $0.80-3.6$ \\
\hline SC & - & $0.48 \pm 0.10$ & $0.26-0.72$ & $0.58 \pm 0.12$ & $0.31-0.90$ \\
\hline $\mathrm{FC}$ & - & $2.61 \pm 0.51$ & $1.69-4.20$ & $0.64 \pm 0.29$ & $0.21-2.20$ \\
\hline SI & - & $61.0 \pm 17.4$ & $27.6-103.9$ & $21.4 \pm 5.60$ & $7.70-36.0$ \\
\hline $\mathrm{CI}$ & - & $1.24 \pm 0.18$ & $0.95-1.81$ & $0.36 \pm 0.09$ & $0.17-0.63$ \\
\hline
\end{tabular}

where: SD - standard deviation; DBH - diameter at breast height, measured at $1.30 \mathrm{~m}$ above ground $(\mathrm{cm}) ; \mathrm{h}-$ total height (m); cih - height from the crown insertion point $(\mathrm{m})$; ch - commercial height $(\mathrm{m})$; $\mathrm{cl}$ - crown length (m); cd - crown diameter (m); SC (slenderness coefficient) - h/DBH; FC (formal of crown) - cd/cl; SI (salience index) - cd/DBH; CI (coverage index) $-\mathrm{cd} / \mathrm{h}$.

Table 2. Statistic criteria used to evaluate the adjusted models. Tabela 2. Critérios estatísticos usados para avaliar os modelos ajustados.

\begin{tabular}{lc}
$\begin{array}{l}\text { Statistical } \\
\text { criteria }\end{array}$ & Expression \\
\hline $\begin{array}{l}\text { Coefficient of } \\
\text { determination } \\
(3)\end{array}$ & $\mathrm{R}^{2}=1-\left[\frac{\sum_{\mathrm{i}=1}^{\mathrm{n}}\left(\mathrm{Y}_{\mathrm{i}}-\widehat{\mathrm{Y}}\right)^{2}}{\sum_{\mathrm{i}=1}^{\mathrm{n}}\left(\mathrm{Y}_{\mathrm{i}}-\overline{\mathrm{Y}}\right)^{2}}\right]$ \\
$\begin{array}{l}\text { (Root Mean } \\
\text { Square Error } \\
(4)\end{array}$ & RMSE $=\sqrt{(\mathrm{n}-\mathrm{p})^{-1} \sum_{\mathrm{i}=1}^{\mathrm{n}}\left(\mathrm{Y}_{\mathrm{i}}-\widehat{\mathrm{Y}}\right)^{2}}$ \\
$\begin{array}{l}\text { Residual value } \\
(\%)(5)\end{array}$ & Residual value $(\%)=\frac{\mathrm{Y}_{\mathrm{i}}-\widehat{\mathrm{Y}}}{\mathrm{Y}_{\mathrm{i}}} \cdot 100$ \\
\hline
\end{tabular}

Where: $Y_{i}$ - observed variable; $\widehat{Y}$ - estimated variable; $\bar{Y}-$ mean observed variable; $\mathrm{n}-$ number of observations; $\mathrm{p}-$ number of estimated coefficients.

\section{RESULTS}

\subsection{Population structure}

The studied population of $P$. angolensis showed a typically decreasing diameter distribution, with trees up to the class of $67.5 \mathrm{~cm}$. B. madagascariensis also showed a decreasing distribution, with a smaller number of trees in the first class, probably resulting from the already established lack of natural regeneration, what can lead to population decrease throughout time (Figure 3). In the sample, $171 \mathrm{P}$. angolensis $(10.0 \leq \mathrm{DBH} \leq 66.7 \mathrm{~cm})$ and 115 B. madagascariensis $(10.0 \leq$ $\mathrm{DBH} \leq 38.6 \mathrm{~cm}$ ) were measured in $6 \mathrm{ha}$, corresponding to 28.5 and 19.2 trees.ha ${ }^{-1}$, respectively.

\subsection{Morphometric relationship}

The mean height for the two species was $\approx 11.0 \mathrm{~m}$, with a similar height range for both $P$. angolensis $(5.6 \mathrm{~m}$ and $17.6 \mathrm{~m})$ and B. madagascariensis $(6.5 \mathrm{~m}$ and $16.0 \mathrm{~m})$. The measured values of crown diameter varied between $3.80 \leq \mathrm{cd} \leq 9.30$ for $P$. angolensis, and $0.80 \leq \mathrm{cd} \leq 3.6$ for B. madagascariensis. $\mathrm{DBH}$ also showed an expressive difference between the two species, being $10.0 \leq \mathrm{DBH} \leq 66.7 \mathrm{~cm}$ and $10.0 \leq \mathrm{DBH} \leq$
$38.6 \mathrm{~cm}$, respectively, for $P$. angolensis and B. madagascariensis. The other measured variables showed homogeneous dimensions. The biometric model showed a specific performance for each morphometric variable assessed as dependent variable for $P$. angolensis and B. madagascariensis (Table 3).

All $P$. angolensis regressions that describe the morphometric variables according to $\mathrm{DBH}$ as well as the regression coefficient (for $\alpha=5 \%$ ) were significant. The lowest expression of the $\mathrm{R}^{2}$ coefficient was 0.13 in the ch relationship, indicating the low adjusted in $\mathrm{cl}$ the increase of tree diameter, also confirmed by the RMSE of $0.86 \mathrm{~m}$. The relationships of FC with $\mathrm{R}^{2}=0.34$ and CI with $\mathrm{R}^{2}=0.35$, confirmed the lower dependence to $\mathrm{DBH}$. The adjusted regressions for the other variables had $\mathrm{R}^{2}$ values higher than 0.80 and significant coefficients.

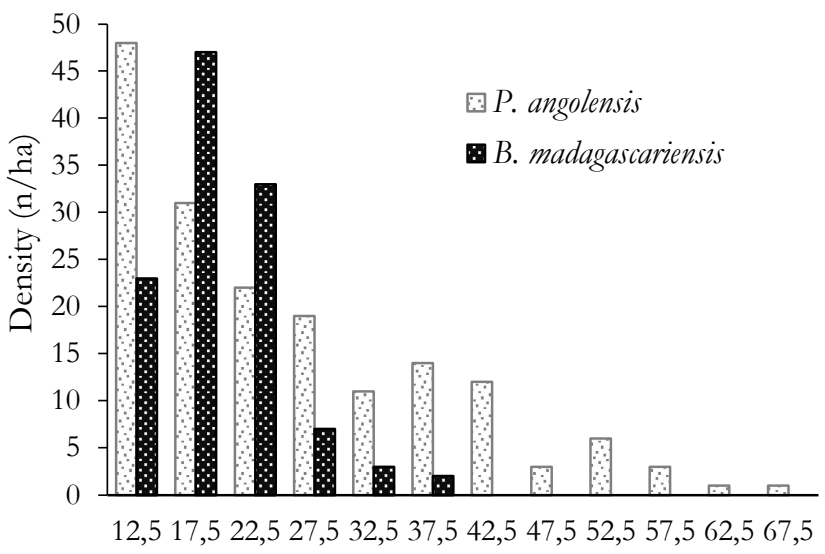

Diameter class $(\mathrm{cm})$

Figure 3. Diameter distribution of Pterocarpus angolensis (grey pillar) and Bobgunnia madagascariensis (black pillar) in Mocuba District, Mozambique.

Figura 3. Distribuição diamétrica de Pterocarpus angolensis (pilar cinza) e Bobgunnia madagascariensis (pilar preto) no Distrito de Mocuba, Moçambique. 
The evaluated for B. madagascariensis showed similar results for the variables FC and CI with a non-significant regression coefficient $(\beta 1)$, indicating that there is no trend data for the assessed equations. Though the morphometry of $P$. angolensis and B. madagascariensis was adjusted with distinct accuracy, the biometric model allowed to precisely describe the mean development of morphometric variables of the two species. The graphs in Figure 4, evidence the variables cd and cih as the ones with the highest difference between species, affecting the other morphometric indexes that contain these variables.

Table 3. Estimated regression coefficients and statistics of adjustment and precision of the dimensional variables of Pterocarpus angolensis and Bobgunnia madagascariensis, in Miombo woodland in Mocuba District, Mozambique.

Tabela 3. Coeficientes de regressão estimados e estatísticas de ajuste e precisão das variáveis dimensionais de Pterocarpus angolensis e Bobgunnia madagascariensis, na floresta de Miombo no Distrito de Mocuba, Moçambique.

\begin{tabular}{|c|c|c|c|c|c|c|c|c|}
\hline Variables & Species & $\mathrm{n}$ & $\beta_{0}$ & $\beta_{1}$ & $\mathrm{~F}$ value & $p$ value $>F$ & $\mathrm{R}^{2}$ & RMSE \\
\hline $\mathrm{h}$ & \multirow{9}{*}{ 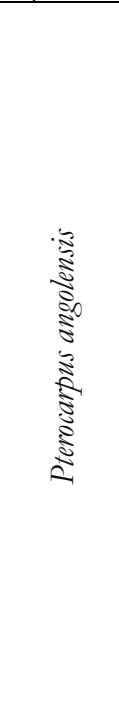 } & \multirow{9}{*}{171} & $\begin{array}{c}203.631 \\
(<0.0001)\end{array}$ & $\begin{array}{l}-129.856 \\
(<0.0001)\end{array}$ & 19426.1 & $<0.0001$ & 0.94 & 0.76 \\
\hline cih & & & $\begin{array}{c}99.362 \\
(<0.0001)\end{array}$ & $\begin{array}{l}-117.056 \\
(<0.0001)\end{array}$ & 7453.71 & $<0.0001$ & 0.83 & 0.63 \\
\hline $\mathrm{ch}$ & & & $\begin{array}{c}5.284 \\
(<0.0001)\end{array}$ & $\begin{array}{c}-3.472 \\
(<0.0001)\end{array}$ & 2170.16 & $<0.0001$ & 0.13 & 0.89 \\
\hline $\mathrm{cl}$ & & & $\begin{array}{c}9.998 \\
(<0.0001)\end{array}$ & $\begin{array}{c}-8.429 \\
(<0.0001)\end{array}$ & 17000.8 & $<0.0001$ & 0.87 & 0.86 \\
\hline $\mathrm{cd}$ & & & $\begin{array}{c}10.477 \\
(<0.0001)\end{array}$ & $\begin{array}{c}-14.409 \\
(<0.0001)\end{array}$ & 5929.56 & $<0.0001$ & 0.85 & 0.67 \\
\hline SC & & & $\begin{array}{c}167.379 \\
(<0.0001)\end{array}$ & $\begin{array}{c}-0.402 \\
(<0.0001)\end{array}$ & 11703.8 & $<0.0001$ & 0.83 & 4.24 \\
\hline $\mathrm{FC}$ & & & $\begin{array}{c}5.429 \\
(<0.0001)\end{array}$ & $\begin{array}{c}-0.237 \\
(<0.0001)\end{array}$ & 3405.19 & $<0.0001$ & 0.34 & 0.42 \\
\hline SI & & & $\begin{array}{c}330.491 \\
(<0.0001)\end{array}$ & $\begin{array}{c}-0.553 \\
(<0.0001)\end{array}$ & 7964.05 & $<0.0001$ & 0.86 & 6.54 \\
\hline $\mathrm{CI}$ & & & $\begin{array}{c}2.190 \\
(<0.0001)\end{array}$ & $\begin{array}{c}-0.184 \\
(<0.0001)\end{array}$ & 5923.58 & $<0.0001$ & 0.35 & 0.15 \\
\hline $\mathrm{h}$ & \multirow{9}{*}{ 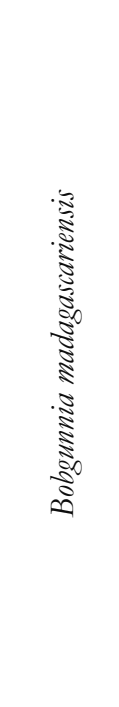 } & \multirow{9}{*}{115} & $\begin{array}{c}17.165 \\
(<0.0001)\end{array}$ & $\begin{array}{c}-8.201 \\
(<0.0001)\end{array}$ & 2452.08 & $<0.0001$ & 0.36 & 1.69 \\
\hline cih & & & $\begin{array}{c}5.270 \\
(<0.0001)\end{array}$ & $\begin{array}{c}-4.598 \\
(<0.006)\end{array}$ & 957.65 & $<0.0001$ & 0.07 & 1.01 \\
\hline $\mathrm{ch}$ & & & $\begin{array}{c}7.532 \\
(<0.0001)\end{array}$ & $\begin{array}{c}-9.461 \\
(<0.006)\end{array}$ & 1111.61 & $<0.0001$ & 0.25 & 1.03 \\
\hline $\mathrm{cl}$ & & & $\begin{array}{c}2.866 \\
(<0.0001)\end{array}$ & $\begin{array}{c}-6.729 \\
(<0.0001)\end{array}$ & 1355.75 & $<0.0001$ & 0.18 & 0.41 \\
\hline $\mathrm{cd}$ & & & $\begin{array}{c}12.199 \\
(<0.0001)\end{array}$ & $\begin{array}{c}-10.549 \\
(<0.0001)\end{array}$ & 887.67 & $<0.0001$ & 0.24 & 1.77 \\
\hline SC & & & $\begin{array}{c}274.6 \\
(<0.0001)\end{array}$ & $\begin{array}{c}-0.529 \\
(<0.0001)\end{array}$ & 2367.21 & $<0.0001$ & 0.45 & 9.27 \\
\hline FC & & & $\begin{array}{c}1.117 \\
(<0.0375)\end{array}$ & $\begin{array}{c}-0.190 \\
(<0.2451)\end{array}$ & 276.58 & $<0.0001$ & 0.01 & 0.29 \\
\hline SI & & & $\begin{array}{c}118.173 \\
(<0.0001)\end{array}$ & $\begin{array}{c}-0.587 \\
(<0.0001)\end{array}$ & 1413.26 & $<0.0001$ & 0.37 & 4.37 \\
\hline CI & & & $\begin{array}{c}0.463 \\
(<0.0001)\end{array}$ & $\begin{array}{c}-0.078 \\
(<0.3653)\end{array}$ & 1002.74 & $<0.0001$ & 0.01 & 0.09 \\
\hline
\end{tabular}

where: $\mathrm{n}$ - number of measured trees in the 6.0 ha sampled; $\mathrm{h}$ - total height, in $\mathrm{m}$; cih - crown insertion height, in $\mathrm{m}$; ch commercial height, in $\mathrm{m}$; DBH - diameter at breast height, in cm; $\mathrm{cl}$ - crown length, in $\mathrm{m}$; cd - crown diameter, in $\mathrm{m}$; SC (slenderness coefficient) - h/DBH; FC (formal of crown) - cd/cl; SI (salience index) - cd/DBH; CI (coverage index) - cd/h; $\beta_{0}, \beta_{1}$ - estimated regression coefficients; $\mathrm{R}^{2}$ - coefficient of determination; RMSE - root mean squared error; $p$ value $>F-$ probability value of the $F$-test; ( ) - probability value of $t$-test for estimated regression coefficients.

\section{DISCUSSION}

The negative exponential diametric distribution (Figure 3) for $P$. angolensis suggests that the natural regeneration process and the continued survival of the species in the forest are ensured (CARO et al., 2005; DE CAUWER et al., 2014; VAN HOLSBEECK et al., 2016; HOFIÇO et al., 2018). According to Caro et al. (2005), this behaviour is due to the fact that the species is adapted to survive and tolerate severe environmental conditions such as fires and droughts.

Nevertheless, the unimodal diametric distribution of $B$. madagascariensis can indicate the critical absence of natural regeneration or plant mortality due to anthropic action, which is recurrent in the region, as reported by Williams et al. (2008) and Ryan; Williams (2011), in woodland recovery during Miombo regeneration in Central Mozambique. 

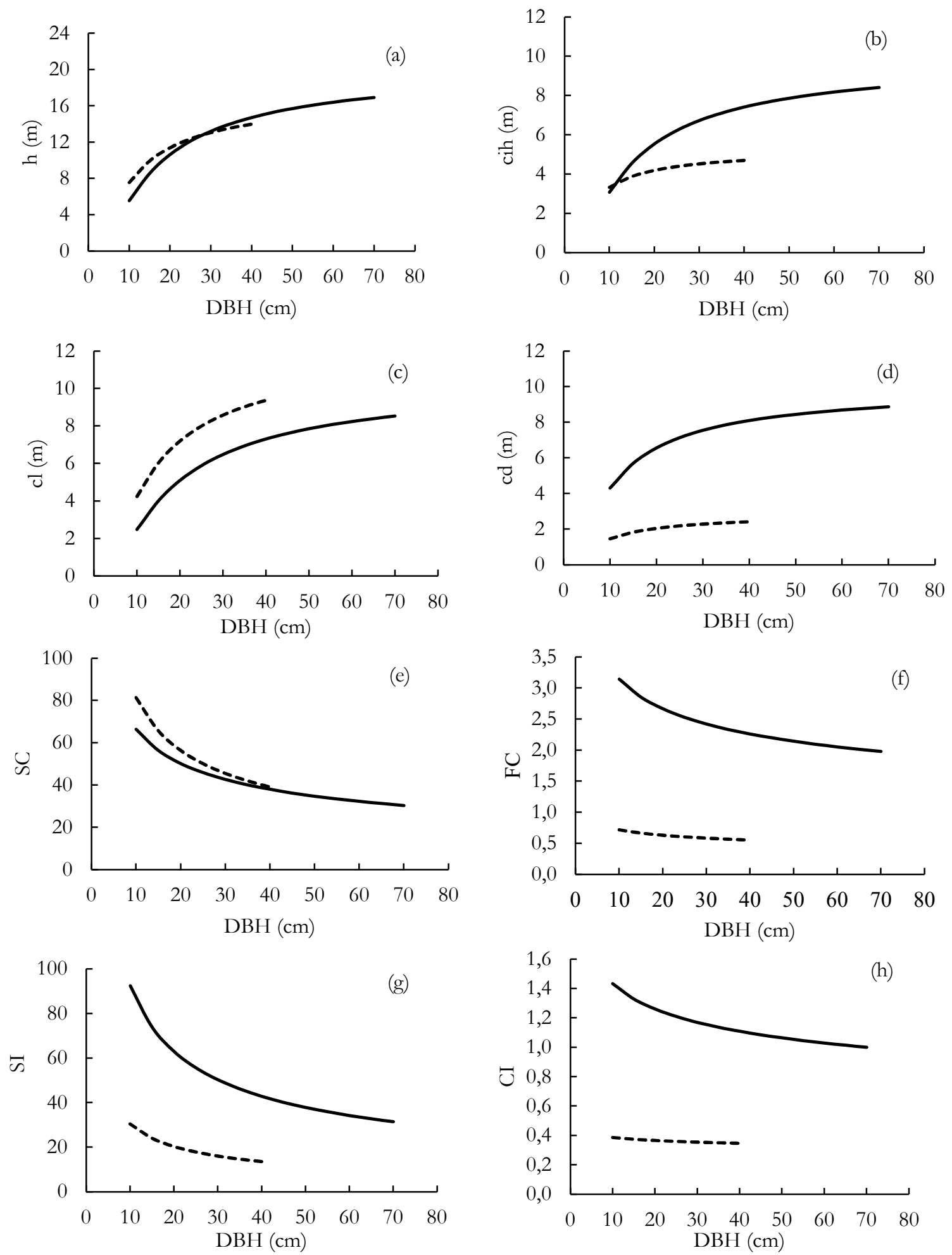

Figure 4. Adjusted regressions lines according to the dimensional variables for Pterocarpus angolensis (solid line) and Bobgunnia madagascariensis (dotted line) trees in Miombo woodland in Mocuba District, Mozambique.

Figura 4. Linhas de regressões ajustadas de acordo com as variáveis dimensionais para árvores de Pterocarpus angolensis (linha contínua) e Bobgunnia madagascariensis (linha pontilhada) na floresta de Miombo no Distrito de Mocuba, Moçambique.

In addition to the anthropic action in the area, there is the hypothesis that it occurs due to fires, which eliminate a considerable number of regenerating trees when it goes beyond human control, altering the structure of specific populations in the Miombo ecosystem (WILLIAMS et al.,
2008; CHIDUMAYO, 2013; RIBEIRO et al., 2017). This fact is integrated with studies in the Miombo ecosystem, in which the negative influence of fires and the anthropic disturbances in species ecological process - including natural regeneration - are reported (CARO et al.; 2005; WILLIAMS 
et al., 2008; SYAMPUNGANI et al., 2016). In the specific case of $P$. angolensis, it is possible to affirm that there still is anthropic action for wood extraction in the study site.

Heights had a great significance in the understanding of the features of these two species, which showed a high structural complexity, reflected in the low $\mathrm{R}^{2}$ values of the equations developed for the analysed morphometric variables of $B$. madagascariensis. Sampled B. madagascariensis trees were relatively young, with low variability of the analysed dimensional characteristics.

These differences can be explained by the phenotypical resilience of tree response to climate and other environmental conditions such as altitude and soil features (KALABA et al., 2013; SEIFERT et al., 2014), as well as the action of fires, observed in the woodland, in which some trees of B. madagascariensis had their trunks and crowns damaged. It is important to mention that both $B$. madagascariensis and $P$. angolensis are species of the same forest formation and belong to the same family (Fabaceae) but to different ecological groups: the first is a late-climax secondary species whereas the latter is a pioneer species (GONÇALVES et al., 2017; CHITECULO; SUROVY 2018), in other words, ecological strategies are different to obtain better results for species growth and survival (WILLIAMS et al., 2008; CHIDUMAYO, 2013). Chidumayo (2019) report different strategies of trees in the Miombo canopy where he found that most pioneer species grow slower in the initial stages.

Crown length (cl) increased with DBH for both species (Figure 3c), and B. madagascariensis was higher than $P$. angolensis. This fact can be $B$. madagascariensis explained by the shape of some B. madagascariensis trees observed in the studied forest, which had multiple high stems and sparse crown, contrary to the common feature of trees in the Miombo woodland, which typically have flat and round umbel-shaped crowns like $P$. angolensis (MATE et al., 2014; DE CAUWER et al., 2014). Feldpausch et al. (2011) observed that the apical growth speed of leafy species is higher for some species than the mortality of branches in the crown basis, what results in a higher crown proportion, being this variable an indicator of tree vitality as well as an indicator of degree of competition.

The same increase was verified for crown diameter in which $P$. angolensis and B. madagascariensis varied between 3.8 and $9.3 \mathrm{~m}$, and 0.8 and $3.6 \mathrm{~m}$, respectively (Table 1$)$. It was noted that $B$. madagascariensis showed a slight reduction in the increase rate of crown diameter in higher $\mathrm{DBH}$ classes (Figure 4d), what can indicate that a smaller space is needed for side growth, consequently displaying a smaller area of crown projection (ROMAN et al., 2009; SYAMPUNGANI et al., 2016; HESS et al., 2016). P. angolensis showed an increase in insertion height crown and crown diameter as trees grew in diameter (Figure $4 \mathrm{~b}$ and $4 \mathrm{~d}$ ). The high variability in the dimensions of the crown can be related to the different degrees of competition to which the tree is subjected (SEIFERT et al., 2014; HESS et al., 2021).

However, this aspect, in the present work, is conflicting, since the trees of $P$. angolensis and B. madagascariensis have little influence from competition (MUGASHA et al., 2013; DE CAUWER et al., 2014; MATE et al., 2015), as competition becomes relevant only when there is light restriction (PRETZSCH, 2009; ROMAN et al., 2009). Mugasha et al. (2013) reported that as crowns grow their height increases, and crowns are wider and need more space for growth, what justifies the crown dimensions and tree height relationship.
Trees with large and healthy crowns are related to higher growth rates as a result of the increase in the photosynthesis rate (VON HOLSBEECK et al., 2016; FU et al., 2017).

Taking the slenderness coefficient ( $h / D B H)$ into consideration, B. madagascariensis showed higher values than P. angolensis (Table 1; Figure 4e). However, this feature tends to decrease as DBH increases, indicating a higher stability of trees, provided by the smaller $\mathrm{DBH} /$ total tree height relationship, regardless of age (FELDPAUSCH et al., 2011; MUGASHA et al., 2013). The decrease of the slenderness coefficient is a positive physiological factor for stability since trees with very high stems and small diameters are more unstable, specially under the action of wind, which is impossible to be controlled (MUGASHA et al., 2013; SEIFERT et al., 2014) and can cause irreversible damage such as crown breakage or tree fall (GONZALEZBENECKE et al., 2014).

The FC with mean value of 2.61 for $P$. angolensis (Table 1) indicates large crowns distinctive of the species, which has ellipsoidal, flat or umbel-shaped crowns according to De Cauwer et al. (2014). B. madagascariensis showed mean FC of 0.64 , with slender and sparse crowns. The SI which expresses how larger the crown diameter is than the $\mathrm{DBH}$ (MUGASHA et al., 2013; HESS et al., 2021), was 61.0 for $P$. angolensis, in other words, the crown diameter is 61 times larger than the $\mathrm{DBH}$ - and 21.4 for B. madagascariensis (Table 1, Figure 4g).

A lower value of the SI means that the tree has a proportionally higher crown surface area, making a more efficient use of space, thus considering a given crown projection area. Therefore, as trees grow within the forest, this index can be used as a thinning indicator, establishing the space to be cleared (GETZIN et al., 2011; GONZALEZBENECKE et al., 2014).

The variable of the CI can also be used for species management as it indicates the necessary space for the target height (JUCKER et al., 2015; HESS et al., 2016). The mean value for $P$. angolensis and B. madagascariensis was 1.24 and 0.36 , respectively (Table 1). This index showed an almost curvilinear tendency as trees grew in height, as demonstrated by this study (Figure 4h). This trend is a result of the small increase of crown diameter with the increase of height in the sampled classes, although no increase in height was observed. The higher the value for this index, evidences that their growth is larger in height than in DBH (FELDPAUSCH et al., 2011).

We believe that for these activities to be successful, growth data for valuable timber species such as those presented in this study need to be widely available and we hope this information can help inform the sustainable management of timber in Mozambique.

\section{CONCLUSIONS}

There are significant and statistically precise relationships for interdimensional and morphometric features of $P$. angolensis, where crown diameter and crown length increase as $\mathrm{DBH}$ and height increase, the larger the crown, the larger the species growth, except for B. madagascariensis, whose crown features were little related to $\mathrm{DBH}$.

The high variability of canopy diameters probably occurs due to the specific and adverse environmental conditions that influence the growth of the species, confirming the resilience characteristic of the same, high adaptation capacity. Crown 
features are the main factors that influence tree growth and timber quality, and they are important information for forest management measures, due to the simplicity and practicality of application in natural forests.

This study can contribute through silvicultural interventions that result in better increment rates and native species growth in the context of management of individual tree and conservation of species in a natural forest. The results are relevant to conservation and sustainable management for $P$. angolensis and B. madagascariensis trees in central of Mozambique.

\section{ACKNOWLEDGMENTS}

We thank Sotomane concession staff and colleagues from the Department of Forest Engineering at UniZambeze for their support. Special thanks are due to Mr. Jaime Macuacua, Marchante Assura and Miguel da Costa for important contributions during the execution of this work. This research was supported by the National Research Fund of Mozambique (FNI: Project_12B/2018).

\section{REFERENCES}

ALI, A. C.; UETIMANE JUNIOR, E.; LHATE, I. A.; TERZIEV, N. Anatomical characteristics, properties and use of traditionally used and lesser-known wood species from Mozambique: a literature review. Wood Science and Technology, New York, v. 2, n. 6, p. 453-472, 2008. DOI: https://doi.org/10.1007/s00226008-0186-5

BUNSTER, J. Commercial timbers of Mozambique: Technological Catalogue. Traforest Lda, Maputo, Mozambique. 2006. 63p.

CAMPBELL, B.; ANGELSEN, A.; CUNNINGHAM, A.; KATERERE, Y.; SITOE, A.; WUNDER, S. Miombo woodlands: Opportunities and barriers to sustainable forest management. Centre for International Forestry Research (CIFOR), Bogor, Indonesia. 2008. 41p.

CARO, T. M.; SUNGULA, M.; SCHWARTZ, M. W.; BELLA, E. M. Recruitment of Pterocarpus angolensis in the wild. Forest Ecology and Management, Amsterdam, v. 219, n. 2-3, p. 69-175, 2005. DOI: https://doi.org/10.1016/j.foreco.2005.07.004

CHIDUMAYO, E. N. Forest degradation and recovery in a Miombo woodland landscape in Zambia: 22 years of observations on permanent sample plots. Forest Ecology and Management, Amsterdam, v. 291, p. 154161, 2013.2 DOI: https://doi.org/10.1016/j.foreco.2012.11.031

CHIDUMAYO, E. N. Management implications of tree growth patterns in Miombo woodlands of Zambia. Forest Ecology and Management, Amsterdam, v. 436, n. 1 , p. 105-116, 2019. DOI: https://doi.org/10.1016/j.foreco.2019.01.018

CHITECULO, V.; SUROVY, P. Dynamic Patterns of trees species in Miombo Forest and management perspectives for sustainable production - case study in Huambo Province, Angola. Forests, Basel, v. 9, n. 6, p. 321, 2018. DOI: https://doi.org/10.3390/f9060321

COSTA, E. A.; FINGER, C. A. G.; FLEIG, F. D. Influência da posição social nas relações morfométricas de Araucaria angustifolia. Ciência Florestal, Santa Maria, v.
26, n. 1, p. 225-234, 2016. DOI: http:/ /dx.doi.org/10.5380/rf.v47i4.49667

DE CAUWER, V.; MUYS, B.; REVERMANN, R.; TRABUCCO, A. Potential, realised, future distribution and environmental suitability for Pterocarpus angolensis DC in southern Africa. Forest Ecology and Management, Amsterdam, v.315, n. 1, p. 211-226, 2014. DOI: https://doi.org/10.1016/j.foreco.2013.12.032

EGAS, A. Assessment of harvested volume and illegal logging in Mozambican natural forests. Faculty of Agronomy and Forest Engineering, Eduardo Mondlane University. Maputo, Moçambique. 2013. 176p.

FELDPAUSCH, T. et al. Height-diameter allometry of tropical forest trees. Biogeosciences, Hoboken, v. 8, p. 1081-1106, 2011. DOI: https://doi.org/10.5194/bg-81081-2011

GELDENHUYS, C. J. Basic guidelines for silvicultural and management practices in Mozambique. Report FW-04/05, Forestwood, Pretoria, 2005. 78p.

GETZIN, S.; WORBES, M.; WIEGAND, T.; WIEGAND, $K$. Size dominance regulates tree spacing more than competition within height classes in tropical Cameroon. Journal of Tropical Ecology, Cambridge, v. 27, n. 1, p. 93-102, 2011.

DOI: https://doi.org/10.1017/S0266467410000453

GONÇALVES, F. M. P.; REVERMANN, R.; GOMES, A. L.; AIDAR, M. P. M.; FINCKH, M.; JUERGENS, N. Tree species diversity and composition of Miombo woodlands in South-Central Angola: A chronosequence of forest recovery after shifting cultivation. International Journal of Forestry Research, London, v. 2017, n. 1, p. 1-13, 2017. DOI: https://doi.org/10.1155/2017/6202093

GONZALEZ-BENECKE， C. A.; GEZAN, S. A.; SAMUELSON, L. J.; CROPPER Jr., W. P.; LEDUC, D. J.; MARTIN, T. A. Estimating Pinus palustris tree diameter and stem volume from tree height, crown area and stand-level parameters. Journal of Forest Research, v. 25 , n. 1, p. 43-52, 2014. DOI: https://doi.org/10.1007/s11676-014-0427-4

HESS, A. F.; MINATTI, M.; COSTA, E. A.; SCHORR, L. P. B.; ROSA, G. T. da; SOUZA, I. de A.; BORSOI, G. A.; LIESENBERG, V.; STEPKA, T. F.; ABATTI, R. Height-to-diameter ratios with temporal and dendro/morphometric variables for Brazilian pine in south Brazil. Journal of Forestry Research, v. 32, p. 191-202, 2021. DOI: https://doi.org/10.1007/s11676019-01084-8

HESS, A. F.; LOIOLA, T.; SOUZA, I. A. de; NASCIMENTO, B. Morphometry of the crown of Araucaria angustifolia in natural sites in southern Brazil. Bosque, Valdivia, v. 37, n. 3, p. 603-611, 2016. DOI: http://dx.doi.org/10.4067/S0717-92002016000300017

HOFIÇO, N. S. A.; COSTA, E. A.; FLEIG, F. D.; NANVONAMUQUITXO, S. J. A. Regulation of the diametric structure of the Miombo woodland using the De Liocourt method in Mozambique. Nativa, Sinop, v. 6, n. 4, p. 407-414, 2018. DOI: http://dx.doi.org/10.31413/nativa.v6i4.5396

HOFIÇO, N. S. A.; FLEIG, F. D. Diversity and structure of Miombo woodlands in Mozambique using a range of sampling sizes. Journal of Agricultural Science and Technology, Tarbiat, v. 5, n. 10, p. 679-690, 2015. DOI: 10.17265/2161-6264/2015.10.005 
JUCKER, T.; BOURIAUD, O.; COOMES, D. A. Crown plasticity enables trees to optimize canopy packing in mixed-species forests. Functional Ecology, Oxford, v. 29, p. 1078-1086, 2015. DOI: https://doi.org/10.1111/1365-2435.12428

KALABA, F. K.; QUINN, C. H.; DOUGILL, A. J.; VINYA, R. Floristic composition, species diversity and carbon storage in charcoal and agriculture fallows and management implications in Miombo woodlands of Zambia. Forest Ecology and Management, Amsterdam, v. 304, p. 99-109, 2013. DOI: https://doi.org/10.1016/j.foreco.2013.04.024

KALABA, F. K.; QUINN, C. H.; DOUGILL, A. J. The role of forest provisioning ecosystem services in coping with household stresses and shocks in Miombo woodlands, Zambia. Ecosystem Services, v. 5, p. 143-148, 2014. DOI: https://doi.org/10.1016/j.ecoser.2013.07.008

MAE. Perfil do distrito de Mocuba. Província da Zambézia. Ministério da Administração Estatal. Série Perfis Distritais, Maputo, Mozambique. 2005. 50p.

MALMER, A. General ecological features of Miombo woodlands and considerations for utilization and management. p. 34-42. 2007. (Working Papers of the Finnish Forest Research Institute, v. 50).

MATE, R.; JOHANSSON, T.; SITOE, A. Biomass equations for tropical forest tree species in Mozambique. Forests, Basel, v. 5, p. 535-556, 2014. DOI: https://doi.org/10.3390/f5030535

MATE, R.; JOHANSSON, T.; SITOE, A. Stem Volume Equations for Valuable Timber Species in Mozambique. Journal of Sustainable Forestry, v. 34, n. 8, p. 787-806, 2015.

DOI: http://dx.doi.org/10.1080/10549811.2015.1039043

MITADER. Inventário Florestal Nacional. Ministry of Land, Environment and Rural Development, Maputo, Mozambique. 2018. 118p.

MOJEREMANE, W.; LUMBILE, A. U. A review of Pterocarpus angolensis DC. (Mukwa) an important and threatened timber species of the Miombo woodlands. Research Journal of Forestry, v. 10, n. 1, p. 8-14, 2016. DOI: https://doi.org/10.3923/rjf.2016.8.14

MUGASHA, W. A.; BOLLANDSÅS, O. M.; EID, T. Relationships between diameter and height of trees in natural tropical forest in Tanzania. Southern Forests: a Journal of Forest Science, Makhanda, v. 75, n. 4, v. 221 237, 2013.2 DOI: https://doi.org/10.2989/20702620.2013.824672

PRETZSCH, H. Forest dynamics, growth and yield. Heidelberg: Springer Verlag Berlin. Germany, 2009. $664 p$.

REMANE, I. A. D.; THERRELL, M. D. Tree-ring analysis for sustainable harvest of Millettia stublmannii in Mozambique. South African Journal of Botany, Pretoria, v. 125 , p. 120-125, 2019. DOI: https://doi.org/10.1016/j.sajb.2019.07.012

RIBEIRO, N. S.; CANGELA, A.; CHAUQUE, A.; BANDEIRA, R. R.; RIBEIRO-BRROS, A. I. Characterisation of spatial and temporal distribution of the fire regime in Niassa National Reserve, northern Mozambique. International Journal of Wildland Fire, Rosyn, v. 26, n. 12, p. 1021-1029, 2017. DOI: https://doi.org/10.1071/WF17085

ROMAN, M.; BRESSAN, D. A.; DURLO, M. A. Variáveis morfométricas e relações interdimensionais para Cordia trichotoma (Vell.) Arráb. ex Steud. Ciência Florestal, Santa Maria, v. 19, n. 4, p. 473-480, 2009. DOI: http:/ /dx.doi.org/10.5902/19805098901

RYAN, C. M.; PRITCHARD, R.; McNICOL, I.; OWEN, M.; FISHER, J. A.; LEHMANN, C. Ecosystem services from southern African woodlands and their future under global change. Philosophical Transaction B, London, v. 371, ID 20150312, 2016. DOI: https://doi.org/10.1098/rstb.2015.0312

RYAN, C. M.; WILLIAMS, M. How does fire intensity and frequency affect Miombo woodland tree populations and biomass? Ecological applications, Washington, v. 21, n. 1, p. 48-60, 2011. DOI: https://doi.org/10.1890/091489.1

SEIFERT, T.; SEIFERT, S.; SEYDACK, A.; DURRHEIM. G.; GADOW, K. V. Competition effects in an Afrotemperate forest. Forest Ecosystems, New York, v. 1, n. 13, p. 1-15, 2014. DOI: https://doi.org/10.1186/s40663-014-0013-4

SHIRIMA, D.; TOTLAND, O.; MUNISHI, P. K. T.; MOE, S. R. Does the abundance of dominant trees affect diversity of a widespread tropical woodland ecosystem in Tanzania? Journal of Tropical Ecology, Cambridge, v. 31, n. 4, P. 345-359, 2015. DOI: https://doi.org/10.1017/S0266467415000231

STEVENSON, P. C.; NYIRENDA, S. P.; VEITCH, N. C. Highly glycosylated flavonoids from the pods of Bobgunnia madagascariensis. Tetrahedron Letters, Elmsford, v. 51, n. 36, p. 4727-4730, 2010. DOI: https://doi.org/10.1016/j.tetlet.2010.07.013

SYAMPUNGANI, S.; GELDENHUYS, C. J.; CHIRWA, P. W. Regeneration dynamics of Miombo woodland in response to different anthropogenic disturbances: forest characterisation for sustainable management. Agroforestry Systems, Dordrecht, v. 90, p. 563-576, 2016. DOI: https://doi.org/10.1007/s10457-015-9841-7

VAN WYK, B.; VAN WYK, P. Field guide to trees of Southern Africa. Cape Town: Struik publishers, 2011. 536p.

VAN HOLSBEECK, S.; CAUWER, V. de; RIDDER, M. de; FICHTLER, E.; BEECKMAN, H.; MERTENS, J. Annual diameter growth of Pterocarpus angolensis (Kiaat) and other woodland species in Namibia. Forest Ecology and Management, Amsterdam, v. 373, n. 1, p. 1-8, 2016. DOI: https://doi.org/10.1016/j.foreco.2016.04.031

WEISKITTELAR, H.; KERSHAWJA, D. W.; VANCLAY, J. K. Forest growth and yield modeling. Chichester: John Wiley \& Sons Ltda, 2011. 415p.

WORLD BANK. Trading economics. Mozambique GDP 1980-2019. 2020. Disponível em: https://tradingeconomics.com/mozambique/gdp. 